\title{
Young People's Attitudes to Attractive Work, During and After Upper Secondary School
}

\section{Ing-Marie Andersson'}

PhD, Professor, Dalarna University, School of Technology and Business Studies, Sweden

I Kristina Gunnarsson

PhD, Uppsala University, Department of Occupational and Environmental Medicine, Uppsala, Sweden

\section{Ann Hedlund}

PhD, Dalarna University, School of Technology and Business Studies, Sweden

\section{Gunnar Rosén}

PhD, Professor, Dalarna University, School of Technology and Business Studies, Sweden

\begin{abstract}
Attractive work has been defined as a job position which an individual wants, where the employee experiences job stability and where employee identification and dedication are fostered. The present study is aimed at increasing knowledge about attitude changes to work during young people's transition from school to work-life. A closed cohort, consisting of 225 pupils from graduating classes in 10 upper secondary schools in Sweden, was studied. The most significant result was found in the pupils' expectations regarding work attractiveness while they were still attending school and in the subsequent year, after they had finished school. During school attendance, there were no differences between the groups, while those who did not find employment after school greatly reduced their demands regarding attractive work. Those who managed to get a job maintained the same level of expectation as during their school years, in terms of requirements for an attractive job.
\end{abstract}

\section{KEY WORDS}

Attractive work / industrial workplace / vocational school / work environment / young workers

DOI

10.18291/njwls.v7il.81399

\section{Introduction}

n ever-increasing problem in the 2000s is finding workers with the right skills for employment not only in different sectors in Sweden but also in many other industrialized countries in the world (Berg, 1998; Bigot \& Cuchet, 2003; Nitteberg, 2003;

\footnotetext{
$\overline{{ }^{1} \text { Ing-Marie Andersson, Professor, Dalarna University, SE } 79188 \text { Falun, Sweden E-mail: ima@du.se. }}$
} 
Pors \& Johannsen, 2002; Rauhut, 2002; Yränheikki \& Savolainen, 2000). Due to the lack of suitable workforce, $38 \%$ of employers around the world have difficulties in improving their organizations and job attraction (Manpower, 2015). One of the most important concerns for organizations with regard to survival and development is therefore to strengthen the possibilities for recruiting and retaining skilled personnel (Bakker \& Schaufeli, 2008; Kennemar \& Jagrén, 2008). A key challenge in relation to this is to ensure that labor is largely involved and engaged in the company's production and development. An attractive work situation is essential in order to meet these goals (Marks \& Huzzard, 2008). Åteg and Hedlund (2011) define attractive work as follows: a job position that an individual wants, due to positive job characteristics, in an organization perceived as a positive workplace; a position where the employee experiences job stability; and a position that fosters employee identification and dedication.

It is of great importance for managers to understand adolescents' attitudes to work and their opinions about what makes work attractive, in order to increase the possibility of recruiting and retaining workers with suitable skills.

There are many different theories in attraction research. Holcombe Ehrhart and Ziegert (2005), and Breaugh (2008) discuss applicant attraction that provides the best conditions for recruitment. According to these authors, the concept implies characteristics of the work, or parts of the recruitment, such as the content of advertising, information about the company, or how the recruiter acts. What also comes into play is how those looking for employment see the company, compare how it suits them as a person, and ultimately make a judgment about its attractiveness.

Also relevant in this context are theories about retention, which becomes important in keeping down recruitment costs, maintaining production, and providing customer satisfaction and good return. Several researchers focus on a number of different models. Holtom et al. (2006) emphasize that workers who are satisfied, or have few other options, often remain at their workplace. According to Gardner et al. (2009), experiencing a sense of belonging with the company early on can be achieved by discussing culture, development opportunities, and benefits. Korunka et al. (2008) discuss a third example concerning the relationship between workers and their work environment. Parameters, such as job satisfaction, participation in the organization, and stress factors, are mentioned as having a bearing on attractiveness.

The values of young workers are influenced by many factors. Chaves et al. (2004) conclude that urban 9th-grade students' opinions about the meaning of work are shifting, with their families having a strong influence on the students' perceptions of work. Most of the adolescents, but not all, have the notion that work is to make money to earn a living.

Blustein et al. (2002) state in a school-to-work transition study that socioeconomic background significantly affects adolescents' view of work. Young adults coming from a lower social class have a tendency to only see work as a source of income. Those who come from a higher social class have greater opportunities for self-realization.

Many adolescents are affected in their early years by their parents' perception of work. Another significant impact on their perception of work is their experience of parttime work. In studies of adolescents' attitudes to work, these factors play a role, but it is equally important to consider what next generation's work means. Factors influencing new types of employment are quality of work, leadership, and health and safety (Loughlin $\&$ Barling, 2001). Sustainable good health, as well as good attendance at work, can be 
promoted by a leadership that includes both managerial skills and organizational structure (Dellve, 2007; Eriksson, 2011; Stoetzer, 2014).

Berglund (2001) goes further in his research by looking at attitude patterns to work. He discusses four different patterns: altruistic, materialistic, instrumental, and individualistic. In a second step, he divides the workforce into two groups, consisting of a superior role and a subordinate role in the workplace. In a final step, he ties together the different patterns of attitudes with the two different work situations, so that a subordinate role is linked to altruistic and instrumental patterns, while a superior role is linked to materialistic and individualistic patterns. Berglund concludes that the instrumental attitude, which points out the importance of work as a source of money, implies low loyalty and insufficient salary.

Adolescents' attitudes to work and their opinions about what is attractive are however not static over time. Masdonati et al. (2015) state in their study that work values change during the transition from school to work life. The result is independent of whether the adolescent is employed or not.

The overall aim of the present study is to increase knowledge about changes in attitudes to work during young people's transition from school to work life. The following questions are of interest:

- How important is work and what are the main reasons for working?

- How important are different dimensions for making work attractive?

- How attractive are different aspects in current work, according to young people?

- Are there any indications of differences in attitudes between young people who have managed get a job or not?

\section{Materials and Methods}

\section{Study design}

The study included a two-wave questionnaire, with 2 years between the surveys (baseline year, 2013, and follow-up year, 2015). In the 2013 study, 'Knowledge and experiences of risks among pupils in vocational education', Andersson et al. (2014), the researchers visited the schools, informed the pupils about the study, and asked them to complete a questionnaire with questions about their opinions of attractive work (baseline). Absent pupils received a letter with information about the study; in these cases, the teacher administrated the distribution of the questionnaire and sent the completed questionnaire back to the researchers by post. In 2015, the respondents were contacted for a follow-up study. They were asked to fill in a digital questionnaire, or, if they preferred, a postal questionnaire. If necessary, the contact was followed up by two reminders.

\section{Study group}

The sample of young people was a closed cohort, consisting of 225 pupils from graduating classes in 10 upper secondary schools, located in central Sweden. The pupils 
were studying in the following vocational programs: Industrial technology, Restaurant management and food, Transport, and Handicraft (where pupils specialized in woodwork). In 2013, the pupils participated in a questionnaire study and on that occasion were also invited to participate in the follow-up survey about attractive work. In 2015, the former pupils were contacted by telephone and asked if they still wished to participate in the follow-up study, and if they were employed or unemployed. Eighty-six of the former pupils completed a questionnaire about attractive work; of these former pupils, 69 were employed, and 17 were unemployed, or in further education. Most of the young people who were employed had obtained a job in the branch they were educated for. Thus, the study group consisted of 86 young people (42 men, and 27 women), who participated in both the 2013 and 2015 surveys (Fig. 1).

Figure I Flowchart of study group.

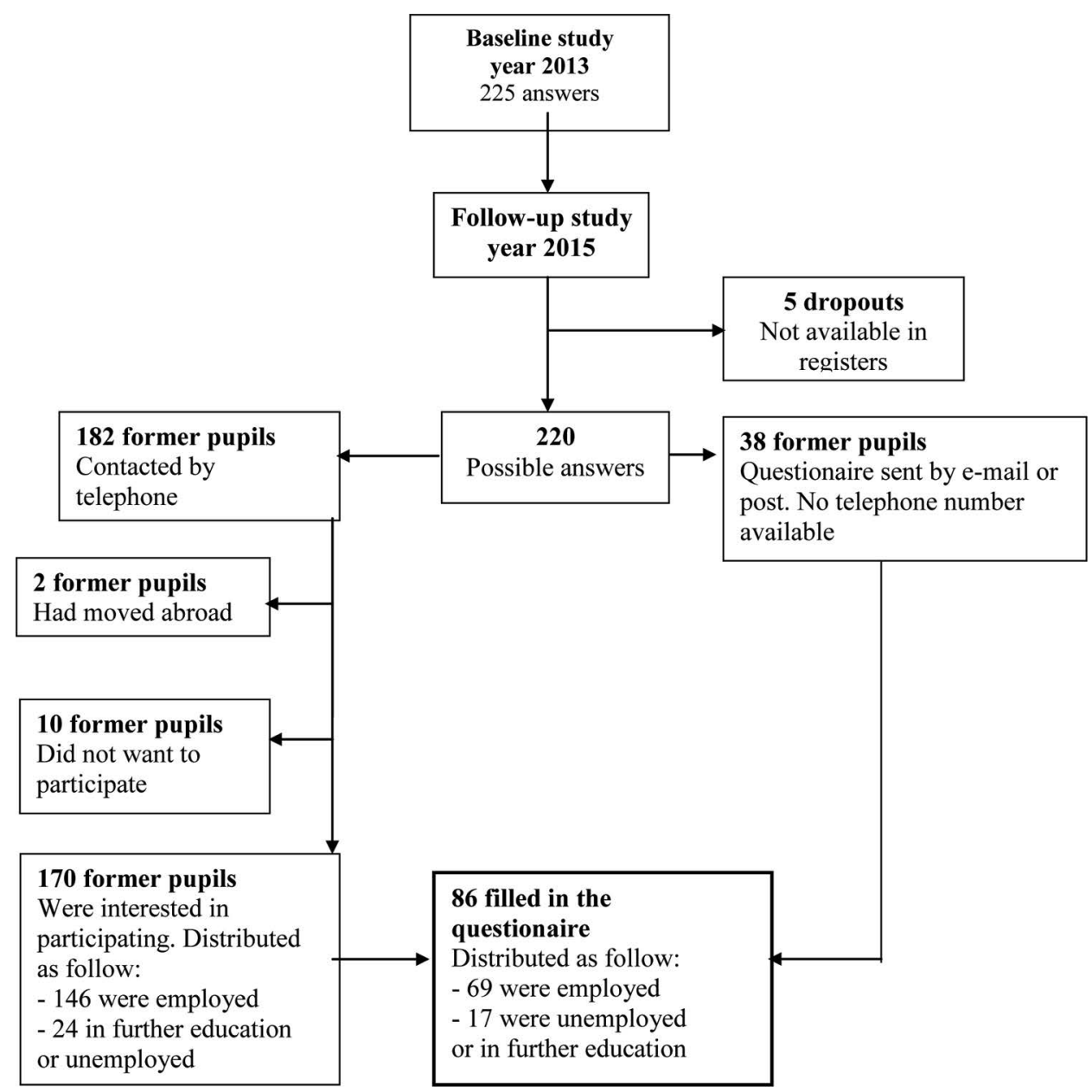




\section{The questionnaire}

The questionnaire about attractive work was developed at Dalarna University in Sweden, according to the attractive work content model (Åteg \& Hedlund, 2011). It starts with two opening questions: 'How important is work to you?', and 'What do you consider as the main reason for working?'. Then follow these questions, divided into three main areas: 'Working conditions', 'Work content', and 'Work satisfaction'. Of the total number of questions, 49 questions were about attractive working conditions, divided into the following ten dimensions: Location, Hours of work, Physical work environment, Suitable equipment, Organization, Leadership, Loyalty, Contact, Relationships, and Salary. There were 18 questions about attractive work content, which were divided into seven dimensions, as follows: Familiarity, Freedom to plan, Physical activity, Mental work, Practical work, Work rate, and Variation. There were 21 questions about work satisfaction, which were divided into five dimensions: Sought after, Stimulation, Outcomes, Acknowledgement, and Status. In the baseline 2013 study, the pupils were asked about their opinions of an optimal workplace. In the follow-up study, employed former pupils were asked to fill in the questionnaire regarding the conditions at their present workplace, as well as what they would like the conditions at an optimal work place to be. Unemployed former pupils and pupils in further education were asked only about an optimal workplace.

\section{Statistical methods}

The answers to each question have been aggregated to dimension value by computing the mean of included questions for each respondent, and thereafter the mean for each group of respondents. Dimension values were analyzed in the statistical program SPSS 23. The size of each sample determined the choice of either a parametric or a nonparametric test. Nonparametric tests were used to compare the results from the unemployed group, due to its small size, and parametric tests were used for the employed group, both in accordance with Hinton et al. (2004). The comparison of the groups' opinions about their main reason for working (Tab. 1) was conducted using the crosstabs with Contingency Coefficient, Phi and Cramer's V, respectively, and Chi-square. Opinions about the importance of attractivity (Tab. 2) were compared, using Wilcoxon Signed Ranks Test (unemployed), and T-test (employed). The comparison between opinions about current work and attractive work (Tab. 3) was conducted using T-test.

\section{Ethics}

This study was approved by the Regional Ethical Committee in Uppsala, Sweden.

\section{Results}

The results are presented in three sections. The first section is a comparison between the answers of the employed group and the unemployed group, regarding the opening 
questions 'How important is work to you?', and 'What do you consider as the main reason for working?'. The second section describes the differences in answers between employed and unemployed, concerning the dimensions of attractivity. The third section describes the employed group's opinions about the conditions of their current work, compared with their wishes for conditions of an optimal workplace.

\section{Opening questions}

\section{'How important is work to you?'}

The young people in the study rate the importance of work as high. On a five-grade scale $(1=$ least important, to $5=$ most important $)$, those who got a job after their examination $(\mathrm{N}=69)$, as well as those who had not $(\mathrm{N}=17), 82 \%$ or more answered 4.0 , or higher on both occasions, in answer to the question, 'How important is work to you?'. Those who had got a job answered 4.39, on average, in the baseline study, and 4.20 in the follow-up study, and the corresponding values for the unemployed group were 4.00, and 4.12, respectively. No significant differences were found between the groups or the occasions.

\section{'What do you consider as the main reason for working?'}

The respondents were also asked what they considered as the main reason for working. The results are presented in Tab. 1.

There are no significant differences between the groups in the baseline study and the follow-up study. In the follow-up study, the unemployed group switched their view of reasons for work with a significantly higher proportion to 'Self-realization and good quality of life'.

A comparison of the 86 , who took part in both the baseline study and the follow-up study, and the other 139, who took part only in baseline study, shows

Table I The study groups' opinions about the main reason for working, in numbers and percentage of three alternatives

\begin{tabular}{|c|c|c|c|c|}
\hline & \multicolumn{2}{|c|}{ Unemployed } & \multicolumn{2}{|c|}{ Employed } \\
\hline & $2013 N=17$ & $2015 N=17$ & $2013 N=69$ & $2015 N=69$ \\
\hline Earning a living and survival & $\begin{array}{c}12 \\
(70 \%)\end{array}$ & $\begin{array}{c}10 \\
(59 \%)\end{array}$ & $\begin{array}{c}43 \\
(62 \%)\end{array}$ & $\begin{array}{c}39 \\
(57 \%)\end{array}$ \\
\hline $\begin{array}{l}\text { Material gain and high } \\
\text { standard of living }\end{array}$ & $\begin{array}{c}2 \\
(12 \%)\end{array}$ & $\begin{array}{c}1 \\
(6 \%)\end{array}$ & $\begin{array}{l}12 \\
(18 \%)\end{array}$ & $\begin{array}{c}10 \\
(14 \%)\end{array}$ \\
\hline $\begin{array}{l}\text { Self-realization and good } \\
\text { quality of life }\end{array}$ & $\begin{array}{c}3 \\
(18 \%)\end{array}$ & $\begin{array}{c}6 \\
(35 \%)\end{array}$ & $\begin{array}{c}14 \\
(20 \%)\end{array}$ & $\begin{array}{c}20 \\
(29 \%)\end{array}$ \\
\hline
\end{tabular}


no significant differences between the two groups regarding the opening questions, 'How important is work to you?', and 'What do you consider as the main reason for working?'.

\section{Attractivity in work}

The main part of the questionnaire focuses on the three following areas: 'Working conditions', 'Work content', and 'Work satisfaction', and how important the underlying dimensions are in making work attractive. In the total baseline study in 2013, the most important dimensions for attractiveness were: Relationships $(\mathrm{m}=4,30)$, including behavior between workmates, Loyalty $(\mathrm{m}=4,16)$ to organization, workplace, and workmates, and Leadership $(\mathrm{m}=4,05)$, including aspects such as confidence, communication, participation, delegation, encouragement. Lowest importance was given to Freedom to plan $(\mathrm{m}=3,20)$ one's own and others work, Location $(\mathrm{m}=3,56)$, including aspects of traveling to and from work, as well as the attractiveness of the surrounding area, and Status $(\mathrm{m}=3,59)$ in terms of work pride and professional identity. No significant differences were found between the two groups of unemployed and employed.

A comparison of the 86 respondents who took part in both the baseline study and the follow-up study, and the other 139, who took part only in the baseline study, indicates a significant difference in four dimensions. Physical work environment, loyalty, and salary were more important for the group of 86 who participated both in 2013 and 2015 , while status was more important for the group of 139 , who only participated in the baseline study in 2013.

Those who were unemployed in 2015 had reduced their wishes in all dimensions, while in 2015, the employed group had almost the same wishes as in 2013. In the unemployed group, significant differences between the baseline and follow-up studies were found in 10 of 22 dimensions. The importance had decreased for all dimensions, and especially the importance of Salary which have been the second most important dimension, and had become the second lowest. The employed group did not significantly change their views when entering working life. In two dimensions, Familiarity and Outcomes, the answers were significantly unchanged. Details are presented in Tab. 2.

\section{The employed group's opinions about current work and an optimal work}

Those who were employed in the follow-up study in 2015 were also asked about their opinion of current job attractiveness. The differences between their wishes regarding different dimensions for work to be attractive, and their opinions of the work they have, are significant in 15 of the dimensions. All the differences are in the same area, namely, that their wishes are not totally fulfilled in their current job. The most important dimension for attractiveness, Relationship, is also the one that is most fulfilled. The differences are biggest in relation to Salary, Stimulation, and Acknowledgement. 
Table 2 The study groups' opinions about dimensions of relative importance in making work attractive

\begin{tabular}{|c|c|c|c|c|c|c|c|}
\hline \multirow[t]{2}{*}{$\begin{array}{l}\text { Attractive } \\
\text { work }\end{array}$} & \multirow[t]{2}{*}{ Dimension } & \multicolumn{3}{|c|}{$\begin{array}{l}\text { Unemployed } 2015 \\
(N=17)\end{array}$} & \multicolumn{3}{|c|}{$\begin{array}{l}\text { Employed } 2015 \\
\quad(N=69)\end{array}$} \\
\hline & & 2013 & 2015 & Difference & 2013 & 2015 & Difference \\
\hline \multirow{10}{*}{$\begin{array}{l}\text { Working } \\
\text { conditions }\end{array}$} & Location & 3.55 & 3.16 & 0.39 & 3.57 & 3.70 & -0.13 \\
\hline & Hours of work & 3.82 & 3.33 & 0.49 & 3.75 & 3.84 & -0.09 \\
\hline & Physical work environment & 4.06 & 3.56 & 0.5 & 3.82 & 3.79 & 0.02 \\
\hline & Suitable equipment & 3.88 & 3.50 & 0.38 & 4.01 & 4.03 & -0.02 \\
\hline & Organization & 3.91 & 3.20 & $0.7 \mid *$ & 3.77 & 3.92 & -0.15 \\
\hline & Leadership & 3.96 & 3.31 & $0.65 *$ & 4.07 & 4.09 & -0.01 \\
\hline & Loyalty & 4.29 & 3.48 & $0.81^{* * *}$ & 4.14 & 4.13 & 0.01 \\
\hline & Contact & 3.85 & 3.04 & $0.81 *$ & 3.87 & 3.93 & -0.06 \\
\hline & Relationships & 4.18 & 3.52 & $0.66 *$ & 4.31 & 4.33 & -0.01 \\
\hline & Salary & 4.27 & 2.75 & $1.52 * * * *$ & 3.88 & 3.79 & 0.10 \\
\hline \multirow{7}{*}{$\begin{array}{l}\text { Work } \\
\text { content }\end{array}$} & Familiarity & 3.91 & 3.19 & 0.72 & 3.84 & 3.85 & $-0.0 \mid$ |***** \\
\hline & Freedom to plan & 3.21 & 2.42 & $0.79 *$ & 3.21 & 3.17 & 0.04 \\
\hline & Physical activity & 3.91 & 3.67 & 0.24 & 3.59 & 3.70 & -0.11 \\
\hline & Mental work & 3.89 & 3.26 & 0.63 & 3.77 & 3.65 & 0.12 \\
\hline & Practical work & 3.94 & 3.14 & $0.8^{*}$ & 4.03 & 3.82 & 0.21 \\
\hline & Work rate & 3.94 & 3.17 & $0.77 *$ & 3.93 & 3.88 & 0.04 \\
\hline & Variation & 3.82 & 3.00 & $0.82 *$ & 3.71 & 3.58 & 0.13 \\
\hline \multirow{5}{*}{$\begin{array}{l}\text { Work } \\
\text { satisfaction }\end{array}$} & Sought after & 4.04 & 3.26 & 0.78 & 3.94 & 3.89 & 0.04 \\
\hline & Stimulation & 3.98 & 3.22 & 0.76 & 4.02 & 3.95 & 0.08 \\
\hline & Outcomes & 3.64 & 3.25 & 0.39 & 3.83 & 3.83 & 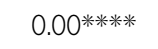 \\
\hline & Acknowledgment & 3.79 & 3.06 & 0.73 & 3.87 & 3.68 & 0.19 \\
\hline & Status & 3.59 & 2.83 & 0.76 & 3.59 & 3.54 & 0.06 \\
\hline
\end{tabular}

Results are presented as averages (on a scale I-5) for the two study groups in the baseline study (2013), and the follow-up study (2015).

*The difference is significant at the 0.05 level (2-tailed).

*** The difference is significant at the 0.0 I level (2-tailed).

**** The difference is significant at the $0.00 \mathrm{I}$ level (2-tailed).

****** Significant similar at the 0.05 level (2-tailed).

Salary, which includes if the salary is sufficient, high, or influenced by performance and increases regularly, and Acknowledgment, which includes both inner and external acknowledgement from workmates, manager, and other people, both belong to the lower half of importance for attractiveness. Stimulation, in terms of interesting work tasks, positively challenging and enabling development, is the fifth most important dimension, and thereby the difference of greater importance. Details are presented in Tab. 3. 
Table 3 The employed group's opinions about dimensions of relative importance in making work attractive, compared with their view of their current work: Averages $(N=69)$

\begin{tabular}{lccc}
\hline Dimension & Attractive & Current & Difference \\
\hline Relationships & 4.33 & 4.01 & $0.31 * * * *$ \\
Loyalty & 4.13 & 3.84 & $0.29 * *$ \\
Leadership & 4.09 & 3.66 & $0.43^{* * * *}$ \\
Suitable equipment & 4.03 & 3.85 & 0.18 \\
Stimulation & 3.95 & 3.39 & $0.56^{* * * *}$ \\
Contact & 3.93 & 3.87 & 0.06 \\
Organization & 3.92 & 3.59 & $0.33^{* * * *}$ \\
Sought after & 3.89 & 3.45 & $0.44^{* * *}$ \\
Work rate & 3.88 & 3.65 & $0.23^{*}$ \\
Familiarity & 3.85 & 3.86 & -0.01 \\
Hours of work & 3.84 & 3.58 & $0.26 *$ \\
Outcomes & 3.83 & 3.72 & 0.12 \\
Practical work & 3.82 & 3.80 & 0.02 \\
Physical work environment & 3.79 & 3.55 & $0.24 *$ \\
Salary & 3.79 & 2.94 & $0.85^{* * * *}$ \\
Location & 3.70 & 3.59 & 0.11 \\
Physical activity & 3.70 & 3.67 & 0.03 \\
Acknowledgement & 3.68 & 3.18 & $0.50^{* * * *}$ \\
Mental work & 3.65 & 3.37 & $0.28^{* * *}$ \\
Variation & 3.58 & 3.33 & $0.25 * *$ \\
Status & 3.54 & 3.17 & $0.37 * * *$ \\
Freedom to plan & 3.17 & 3.03 & $0.14 *$ \\
\hline
\end{tabular}

*The difference is significant at the 0.05 level (2-tailed).

*** The difference is significant at the 0.0 I level (2-tailed).

**** The difference is significant at the $0.00 \mathrm{I}$ level (2-tailed).

\section{Discussion}

In this study, the attitudes to and expectations regarding work were studied for a number of pupils in vocational programs at Swedish upper secondary schools. The investigations were made when the pupils followed their final year of the 3-year program, which focused on work in hotels and restaurants, the transport sector, and the manufacturing industry. A follow-up survey was made the year after the pupils completed the program. In total, 86 pupils were included in the study, of whom 69 managed to get a job, while the other 17 were unemployed. The most significant result is found in the pupils' judgment of work attractiveness when the two groups are compared during their time at school and in the subsequent year. During school attendance, there are no differences between the groups, while those who did not find employment after school greatly reduced their opinion about the importance of many dimensions of attractive work. 
Those who managed to get a job maintained the same level of response as during their school years, in terms of requirements for an attractive job. This is not in accordance with Masdonati et al. (2015), who found that work values change during young people's transition from school to work life. In the present study, the unemployed group has, however, changed their opinions. The biggest difference concerns salary, which decreased drastically from 4.27 (2013) to 2.75 (2015) for the unemployed group. The group of 139 , who only participated in the baseline study, had a significantly lower salary value (3.44), and the employed group also had a lower salary value (3.88). This raises the question if the unemployed group overestimated the importance of salary during their study period. The two groups set a high value on the importance of work in their lives. Adolescents responded on a five-grade scale with an average over 4.0, which is comparable with what 1440 professionals from different professions in Sweden answered to the same questions in a previous study (Hedlund et al., 2010). The average score in that study was 3.8, which in turn was consistent with responses obtained in two other Swedish studies (Bernhardt, 2009; Isaksson et al., 2004). During school attendance, as well as directly after completion of school, the young people indicated that they value work more highly in their lives than other groups of senior professionals. Unemployment in the other group does not seem to have influenced this significantly.

With regard to young people's perception of reasons for working, there are no clear differences between the two groups or in the groups before and after leaving school. The most important reason was stated to be 'Earning a living and survival', but there was also a tendency toward giving greater importance to 'Self-realization and good quality of life', in the total group after leaving school. The distribution of answers to the three options was in good agreement with what the 1440 professionals (Hedlund et al., 2010) responded to the same question. In earlier studies, it is stated that young adults with a tendency to see work as a source of income have a background in a lower social class (Blustein et al., 2002). More than half of the young people in the present study, both in 2013 and 2015, answered 'earning a living and survival' as the main reason for working. A cautious conclusion could then be that they belong to a lower social class.

The priorities of the two groups regarding what makes a work attractive show a similar picture to that which is usually stated by professionals (Hedlund et al., 2010). Relationship, loyalty, and leadership are three dimensions of the 22 listed that are especially important for attractive work in the two groups, both during schooling and after the completion of school. The importance of these dimensions is supported by Loughlin and Barling (2001) as factors influencing new types of employment. Loughlin and Barling's study, as well as the results from this study, not only point out the importance of leadership but also health and safety, and quality of life. In today's work life, good leadership, relationship, and loyalty are important ingredients for a work to be healthy and qualitative (Dellve, 2007; Eriksson, 2011; Stoetzer, 2014).

For the group which found employment, these three dimensions are top priorities, both during school attendance and on completion of school. For those respondents who did not get work, those dimensions were also among the highest. For those who found work, the five key dimensions were identical in the baseline and follow-up study with almost identical ranking. Also, the dimensions for these occasions which the respondents saw as least important showed a similar pattern, although not as clear. Freedom to plan, status, and variation were considered as less important for attractive work. 'Salary' was valued as the second most important dimension in the unemployed group during school, 
but in the after-school group, it was graded as second least important. The change is remarkably large, but can of course be seen as logical in a situation where young people may be forced to change their expectations of getting a job. As indicated initially, the reduction in wishes is clear also for the other dimensions in the unemployed group. In all dimensions, the expectations were lowered. For the dimension in which the change in the requirements for attractive work was the least in the unemployed group (Physical Activity, $3.91>3.67)$, the change was still greater than the dimension among those who had jobs, with the greatest change (Practical work, 4:03 > 3.82).

The young people in our study are in transition from school to work. Their first job after training is manual or service work that can be classified as subordinate. In such a group, an instrumental attitude to work is more frequent (Berglund, 2001).

The group of young people without work has somewhat higher demands on salaries in 2013 than those who obtained work. The importance of salary has decreased dramatically and significantly in the group without work in 2015. The importance of loyalty has also decreased markedly and significantly in 2015. This is interesting, because a group with instrumental attitude (Berglund, 2001) lacks loyalty and believes that salary is inadequate. Could this lead to a situation that when the adolescents in this group get a job, they will not be satisfied with the salary? When they do not see loyalty as important, it will probably be difficult for employers to retain them at work. Berglund (2001) also concluded that those with an instrumental attitude to work do not agree with the company's corporate values and goals, and therefore feel that working conditions do not give them any satisfaction.

An interesting question is what the lowered importance of salary stands for, especially since this group also, to a higher degree, valued 'self-realization and good quality of life' as a main reason for working, in the follow-up study. Have the youngsters really changed their opinion about the importance of salary, depending on the fact that they have continued to study and found other values more important, and that it has become obvious that they have a pretty good life even if they do not have any salary, etc.? On the other hand, can it be that they actually think that salary is important, but have realized that it is not possible to receive a high salary in one's first employment?

The group that found work after leaving school, in addition to questions about what they consider as important for attractive work, also answered questions about how they assessed the same qualities in their current job. In general, they did not find dimensions to be fulfilled, in accordance with what they indicated as important for an attractive work. The differences were significant in 15 of the 22 dimensions, but in most cases, however, the differences were smaller than what was reported in the study of 1440 professionals from different professions in Sweden (Hedlund et al., 2010).

The results indicate that there are development possibilities for raising work attractiveness. The perception of current work should be closely related to opinions of optimal work, in order to make a fit between work characteristics and the individual (Breaugh, 2008; Holcombe Ehrhart \& Ziegert, 2005). The differences between current and optimal work may result in lower job satisfaction, which raises the risk for turnover (Holtom et al., 2006; Korunka et al., 2008). Important dimensions with large differences identify possible development areas for raising attractiveness. By discussing those development opportunities, together with the work culture, management can increase a sense of belongingness for employees (Gardner et al., 2009). This knowledge can be used both in the recruitment process and to retain and engage employees. Working with 
attractiveness must be an ongoing process for a company, especially with regard to a young workforce, since when these workers become more experienced they will no doubt have more alternatives for employment.

\section{Methodological considerations}

The adolescents included in this study cannot be considered a random sample of those who have chosen a program at a vocational upper secondary school. The selection of the schools where the pupils studied does, however, represent different size schools, different combinations of training programs, as well as location in big cities and small towns. In the baseline study, 225 pupils participated. Of these, the majority could be contacted after leaving school, and 86 of these former pupils chose to participate in the follow-up study. This number must be considered acceptable, since the aim is to study changes over time, and no systematic shortfall can be seen regarding different branches. However, the response rate was about $70 \%$ of the unemployed group, and $47 \%$ of the employed group. A comparison of the 86 , who took part in both the baseline study and the followup study, and the other 139, who took part only in baseline study, indicates a significant difference in the following four dimensions: physical work environment, loyalty, salary, and status. The group of former pupils, who were not working 1 year after completing their studies, was small, which in itself is encouraging, but obviously this is problematic when conclusions about differences in results between the two groups are deducted. From Fig. 1, it is obvious that the response rate was clearly higher in the unemployed group than in the other group. Higher motivation, or more time, may be explanations for this, but no firm conclusions can be drawn. Whatever the causes, they cannot be expected to have an impact on the significant differences reported. The 17 former pupils in the group classified as 'unemployed' not only include persons searching for a job but also those who have chosen to continue their studies. It is of course the case that differences can be expected between those subgroups, but the numbers in each group are too small for any clear conclusions to be drawn. The same applies to the comparison between the different vocational programs. To identify significant differences between those subgroups would have required a larger material than what was possible in this study. Despite this, the main findings are significant; those who did not find employment decreased their wishes for an attractive work significantly, while those who found employment retained their wishes. The study design was longitudinal and focused on the participants' opinions about work; for future study, socioeconomic factors could be interesting to include.

\section{Conclusion}

The perception of what is important for attractive work is strongly dependent on whether or not employment is obtained after completing schooling. In the present study, the importance of salary declined for adolescents who have not started professional work. The qualities of attractiveness for work among the youngster group studied, in general, do not fulfill the participants' expectations. This conclusion is similar to that found for employees in several different branches.

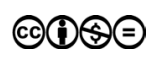




\section{References}

Andersson, I-M., Gunnarsson, K., Moström Åberg, M., Rosén, G. (2014). Knowledge and Experiences of Risks among Pupils in Vocational Education. SH@W Safety and Health at Work, 5, 140-146. doi: http://dx.doi.org/10.1016/j.shaw.2014.06.002.

Åteg, M., Hedlund, A. (2011). Researching attractive work. Analyzing a model of attractive work using theories on applicant attraction, retention and commitment. Arbetsliv i omvandling, 2011:02, 1-34.

Bakker, A. B., Schaufeli, W. B. (2008). Positive organizational behavior: Engaged employees in flourishing organizations. Journal of Organizational Behavior, 29, 147-154. doi: http://dx.doi.org/10.1002/job.515.

Berg, L. (1998). Utdanningssuget. Ungdoms utdannings- og yrkesvalg sett fra skipsindustrien i Ulsteinvik. (Teen education and vocation as seen from the shipping industry in Ulsteinvik) Oslo: Forskningsstiftelsen Fafo.

Berglund T (2001). Attityder till arbete i Västeuropa och USA - Teoretiska perspektiv och analyser av data från sex länder. (Attitudes toward Work in Western Europe and the United States- Theoretical perspectives and empirical analyses of data from six countries.) Dissertation, Department of Sociology, Göteborgs University, Sweden.

Bernhardt E (2009): Familj och Arbetsliv på 2000-talet. (Family and working life in the 2000s.) Retrieved 2016-01-12, from www.sfft.se/dokument/EvaBernhardt.pp.

Bigot, M., Cuchet, E. (2003, 12-15 may 2003). Mechanized harvesting system for hardwoods. Paper presented at the 2nd Forest Engineering Conference, Växjö, Sweden.

Blustein, D. L., Chaves, A. P., Diemer, M. A., Gallagher, L. A., Marshall, K. G., Sirin, S., Bhati, K. S. (2002). Voices of the forgotten half: The role of social class in the school-to-work transition. Journal of Counseling Psychology, 49, 311-321. doi: http://dx.doi.org/10.1037/00220167.49.3.311.

Breaugh, J. A. (2008) Employee recruitment: Current knowledge and important areas for future research. Human Resource Management Review 18(3), 103-118. doi: http://dx. doi.org/10.1016/j.hrmr.2008.07.003.

Chaves A. P., Diemer, M. A., Blustein, D. L., Gallagher, L. A., DeVoy, J. E., Casares, M. T., Perry, J. C. (2004). Conceptions of Work: The View From Urban Youth, Journal of Counseling Psychology vol 51, no 3, 275-286. doi: http://dx.doi.org/10.1037/00220167.51.3.275.

Dellve, L., Skagert, K. \& Vilhelmsson, R. (2007). 'Leadership in workplace health promotion projects: 1 - and 2-year effects on long-term work attendance', European Journal of Public Health, 17, 471-476. doi: http://dx.doi.org/10.1093/eurpub/ckm004.

Eriksson, A. (2011). Health-promotive leadership Doctoral thesis at the Nordic School of Public, Gothenburg, Sweden http://kth.diva-portal.org/smash/record.jsf?dswid=33968pid= diva2:487498.

Gardner, W. L., Reithel, B. J., Foley, R. T., Cogliser, C. C., \& Walumbwa, F. O. (2009). Attraction to Organizational Culture Profiles: Effects of Realistic Recruitment and Vertical and Horizontal Individualism Collectivism. Management Communication Quarterly, 22(3), 437-472. doi: http://dx.doi.org/10.1177/0893318908327006.

Hedlund, A., Andersson, I-M., Rosén, G. (2010). Är dagens arbeten attraktiva? Värderingar hos 1440 anställda. (Is the current work attractive? Values of 1440 employees). Arbetsmarknad och Arbetsliv 16:4, (31-43).

Hinton PR, Brownlaw C, MacMurray I, \& Cozens B. (2004). SPSS Explained. New York: Routledge.

Holcombe Ehrhart, K., Ziegert, J. C. (2005). Why Are Individuals Attracted to Organizations? Journal of Management, 31(6), 901-919. doi: http://dx.doi.org/10.1177/ $\underline{0149026305279759 .}$. 
Holtom, B. C., Mitchell, T. R., Lee, T. W. (2006) Increasing human and social capital by applying job embeddedness theory. Organizational Dynamics, 35(4), 316-331. doi: http://dx.doi.org/10.1016/j.orgdyn.2006.08.007.

Korunka, C., Hoonakker, P., Carayon, P. (2008). Quality of Working Life and Turnover Intention in Information Technology Work. Human Factors and Ergonomics in Manufacturing, 18(4), 409-423. doi: http://dx.doi.org/10.1002/hfm.20099.

Isaksson, K., Johansson, G., Bellaagh, K., Sjöberg, A. (2004). Work values among the unemployed: Changes over time and some gender differences. Scandinavian Journal of Psychology, 45, 207-214. doi: http://dx.doi.org/10.1111/j.1467-9450.2004.00396.x.

Kennemar, J., Jagrén, L (2008). Småföretagsbarometern. (Small Business Barometer.) Stockholm: Swedbank \& Företagarna. http://www.foretagarna.se/globalassets/media/opinion/ smaforetagarbarometern/aldre/h2008.pdf.

Loughlin, C., \& Barling J (2001). Young workers' work values, attitudes, and behaviours, Journal of Occupational and Organizational Psychology, vol 74, issue 4, 543-558. doi: http://dx.doi.org/10.1348/096317901167514.

Manpower. (2015). The Talent Shortage Continues. Retrieved 2016-01-12, from http://www. manpowergroup.com/wps/wcm/connect/0b882c15-38bf-41f3-8882-44c33d0e2952/2014 Talent Shortage WP US2.pdf?MOD=AJPERES.

Marks, A., \& Huzzard, T. (2008). Creativity and workplace attractiveness in professional employment. Journal of Human Resource Costing \& Accounting, 12(3), 225-239. doi: http://dx.doi.org/10.1108/14013380810919868.

Masdonati, J., Fournier, G., Pinault, M., Lahrizi, I. Z., (2015). The evolution of work values during the school-to-work transition: the case of young adults in the 'missing middle'. Int J Educ Vocat Guidance. doi: http://dx.doi.org/10.1007/s10775-015-9300-z.

Nitteberg, M. A. (2003, 12-15 may 2003). Mechanised harvesting in cable operation. Paper presented at the 2nd Forest Engineering Conference, Växjö, Sweden.

Pors, N. O., Johannsen, C. G. (2002). Job satisfaction and motivational strategies among library directors. New Library World, 103, 199-208. doi: http://dx.doi.org/10.1108/ 03074800210433104 .

Rauhut, D. (2002). Arbetskraftsbrist och arbetskraftsinvandring: hot eller möjlighet för ekonomisk tillväxt? (Labor shortage and labor: threat or opportunity for economic growth?) Östersund: ITPS, Institutet för tillväxtpolitiska studier. Document Number A 2002:010.

Stoetzer U, Bergman P, Aborg C, Johansson G, Ahlberg G, Parmsund M, Svartengren M. (2014). Organizational factors related to low levels of sickness absence in a representative set of Swedish companies. Work, 47, 193-205. doi: http://dx.doi.org/10.3233/WOR2012-1472.

Yränheikki, E., Savolainen, H. (2000). Special International Report Occupational Safety and Health in Finland. Journal of Safety Research, 31, 177-183. doi: http://dx.doi. org/10.1016/S0022-4375(00)00039-6 